\title{
Bipedicle-Conjoined Deep Inferior Epigastric Perforator Flaps for Unilateral Breast Reconstruction in Overweight and Obese Patients: Do the Benefits Outweigh the Risks?
}

Steven M. Sultan, MD ${ }^{1}$ Akhil K. Seth, MD $\quad$ Andreas M. Lamelas, MD ${ }^{3}$ David T. Greenspun, MD 3 Heather A. Erhard, MD ${ }^{1}$

${ }^{1}$ Department of Plastic Surgery, Montefiore Medical Center, Address for correspondence Heather A. Erhard, MD, 2 Greenwich Albert Einstein College of Medicine, Bronx, New York

2 Department of Plastic and Reconstructive Surgery, Office Park Suite 210, Greenwich, CT 06831

NorthShore University Health System, Northbrook, Illinois (e-mail: heathererhard@optonline.net).

${ }^{3}$ Department of Plastic Surgery, Greenwich Hospital,

Greenwich, Connecticut

J Reconstr Microsurg 2020;36:346-352.

\begin{abstract}
Background Some surgeons have advocated for the use of bipedicle-conjoined deep inferior epigastric perforator (DIEP) flaps in unilateral autologous breast reconstruction in thin patients in whom a hemiabdominal flap is deemed insufficient. There have been no studies to date, however, exploring complication rates for bipedicle-conjoined DIEP flaps for unilateral reconstruction in overweight or obese patients.

Methods The authors performed a retrospective review of two senior authors' patients from 2013 until 2018. In this time period, 71 patients underwent unilateral breast reconstruction with bipedicle-conjoined DIEP flaps. The patients were divided into normal weight (body mass index $[\mathrm{BMI}]<25, n=30$ ), and overweight/obese $(\mathrm{BMI}>25, n=41)$ groups. Outcomes were reviewed for both major and minor complications.

Results The average BMI of the normal group was $23.1 \pm 1.3 \mathrm{~kg} / \mathrm{m}^{2}$, while the average BMI of the overweight/obese group was $28.9 \pm 4.0 \mathrm{~kg} / \mathrm{m}^{2}(p<0.01)$. There were no significant differences in demographics or comorbidities between the two groups. There were no statistically significant differences in the overall incidence of major or minor complications between the two groups (major: overweight/obese $=12.1 \%$, normal $\mathrm{BMI}=10.0 \%, p=0.39$; minor: overweight $/$ obese $=39.0 \%$, normal $\mathrm{BMI}=36.7 \%$,

\section{Keywords}

- breast reconstruction

- stacked flaps

- deep inferior epigastric perforator microsurgery $p=0.47$ ). The rate of moderate fat necrosis was significantly higher in the overweight/obese group (overweight/obese $=9.8 \%$, normal BMI $=0 \%, p=0.04$ ).

Conclusion Unilateral breast reconstruction with bipedicle-conjoined DIEP flaps can be performed safely in overweight and obese patients. The use of bipedicle-conjoined DIEP flaps in this population allows surgeons to provide overweight or obese patients with reconstructions that are commensurate with their body habitus and/or contralateral breast.
\end{abstract}

received

June 19, 2019

accepted after revision

December 2, 2019

published online

February 3, 2020
Copyright $\odot 2020$ by Thieme Medical

Publishers, Inc., 333 Seventh Avenue, New York, NY 10001, USA

Tel: +1(212) 760-0888.
DOI https://doi.org/ 10.1055/s-0040-1701209. ISSN 0743-684X. 
The use of two abdominally-based flaps for unilateral breast reconstruction is a valuable tool that was first described in 1985 by Ishii et al. ${ }^{1}$ The majority of patients in Ishii's series had large soft-tissue requirements owing to radical mastectomies or radiation necrosis of the chest wall. The authors reconstructed defects using both sides of the lower abdominal wall as pedicled flaps based on the left and right superior epigastric vessels. This technique was refined by Spear who proposed burying one of the two flaps below the other in situations when the skin from a single flap would be sufficient to restore the breast skin envelope, but the volume of a single flap would be insufficient. ${ }^{2}$

More recently, some surgeons have used both hemiabdomens as either "stacked" deep inferior epigastric perforator (DIEP) flaps (two separate DIEP flaps used to reconstruct one breast) or bipedicle-conjoined DIEP flaps (both hemiabdomens transposed with their respective inferior epigastric pedicles as a single conjoined unit) for unilateral breast reconstruction in patients in whom the volume or quantity of skin of a single flap is inadequate to create a breast mound that approximates that of the unaffected contralateral breast. ${ }^{3-5}$ This technique has been applied primarily to patients with a low body mass index (BMI) and accordingly, the volume of flaps used in such reconstructions has been relatively small. ${ }^{6-10}$ DellaCroce et al, for instance, published a series of 55 patients who underwent stacked DIEP flaps for unilateral breast reconstruction over a 3-year period. In their series, the average weight of the patient was 138 pounds (range: $108-190$ pounds), and the average weight of the two DIEP flaps combined for each reconstruction was $596 \mathrm{~g} .{ }^{11}$

Despite the preferential use of bipedicle-conjoined flaps for breast reconstruction in patients with a low-to-normal BMI, the authors believe that many patients on the other end of the BMI spectrum, those in the overweight and obese categories, can also benefit from this technique. In contrast to normal weight patients who present a particular challenge that results from a paucity of donor tissue, many obese and overweight patients possess a premastectomy breast size and morphology that is difficult to replicate with standard reconstructive techniques. These patients, especially those in the obese category (BMI $>30$ ), are considered by many to be poor candidates for autologous reconstruction because of observed increases in complication rates when compared with nonobese patients. ${ }^{12}$ As such, many overweight and obese patients are offered only implant-based reconstruction or no reconstruction at all. ${ }^{13,14}$ This series examines the safety and efficacy of bipedicle-conjoined DIEP flaps for unilateral breast reconstruction in overweight and obese patients.

\section{Methods}

The authors conducted a retrospective review of the two senior authors' patients from 2013 until 2018. In this time period, 71 consecutive patients were identified as having undergone unilateral breast reconstruction with bipedicleconjoined DIEP flaps. These patients were divided into two cohorts: normal weight or underweight $(\mathrm{BMI}<25, n=30)$ and overweight or obese (BMI $>25, n=41$ ). The two cohorts were then compared based on demographic factors, comorbidities, and complications.

Demographics and comorbidities evaluated include age at time of reconstruction, medical comorbidities, and previous abdominal or breast surgery. Medical comorbidities include BMI, hypertension, diabetes, history of chemotherapy, history of prereconstruction radiation, and the use of nicotine within one year of surgery ( - Table 1 ). Operative details reviewed include mastectomy weight and flap weights (initial and final). In addition, the rate of delayed reconstructions and concomitant contralateral procedures were reviewed ( $\mathbf{- T a b l e ~} \mathbf{2}$ ).

Complications were categorized as either major or minor. Major complications included reoperation for any reason during the initial hospitalization, partial or complete flap loss, deep venous thrombosis/pulmonary embolism, and symptomatic bulge formation. Minor complications included wound infection or wound breakdown managed without additional surgery, and seroma formation. Fat necrosis was diagnosed clinically and was categorized as mild $(<2 \mathrm{~cm})$ or moderate $(>2 \mathrm{~cm})$.

The cohorts were compared head to head and comparisons were performed using the student's $t$-test. A value of $p<0.05$ was considered statistically significant. All reported $p$-values correspond to a two-sided test.

\section{Results}

The average BMI in the normal BMI group was $23.1 \pm 1.3 \mathrm{~kg} / \mathrm{m}^{2}$, while the average BMI in the overweight/obese group was

Table 1 Demographics and comorbidities

\begin{tabular}{|c|c|c|c|}
\hline & Normal & $\begin{array}{l}\text { Overweight/ } \\
\text { obese }\end{array}$ & $p$-Value \\
\hline Number & 30 & 41 & NA \\
\hline $\begin{array}{l}\text { Age at } \\
\text { reconstruction (y) }\end{array}$ & $52.8 \pm 7.9$ & $53.2 \pm 8.9$ & 0.42 \\
\hline BMI $\left(\mathrm{kg} / \mathrm{m}^{2}\right)$ & $23.1 \pm 1.3$ & $28.9 \pm 4.0$ & $<0.01$ \\
\hline \multicolumn{4}{|l|}{$\begin{array}{l}\text { Medical } \\
\text { comorbidities (\%) }\end{array}$} \\
\hline $\begin{array}{l}\text { Smoking } \\
\text { (within } 1 \mathrm{y} \text { ) }\end{array}$ & $2(6.7)$ & $4(9.8)$ & 0.34 \\
\hline $\begin{array}{l}\text { Coronary artery } \\
\text { disease }\end{array}$ & $2(6.7)$ & $2(4.9)$ & 0.46 \\
\hline Hypertension & $5(16.7)$ & $14(34.1)$ & 0.06 \\
\hline Diabetes & $1(3.3)$ & $3(7.3)$ & 0.25 \\
\hline $\begin{array}{l}\text { Previous abdominal } \\
\text { surgery (\%) }\end{array}$ & $15(50.0)$ & $22(53.6)$ & 0.44 \\
\hline $\begin{array}{l}\text { Previous breast } \\
\text { surgery (\%) }\end{array}$ & $19(63.3)$ & $22(53.6)$ & 0.16 \\
\hline Chemotherapy (\%) & $14(46.7)$ & $20(48.7)$ & 0.44 \\
\hline $\begin{array}{l}\text { Radiation } \\
\text { therapy (\%) }\end{array}$ & $12(40.0)$ & $20(48.7)$ & 0.27 \\
\hline $\begin{array}{l}\text { Average } \\
\text { follow-up (mo) }\end{array}$ & $31.6 \pm 15.9$ & $27.2 \pm 16.5$ & 0.15 \\
\hline
\end{tabular}

Abbreviations: BMI, body mass index; NA, not available. 
Table 2 Operative details

\begin{tabular}{|l|l|l|l|}
\hline & $\begin{array}{l}\text { Normal } \\
(\boldsymbol{n}=30)\end{array}$ & $\begin{array}{l}\text { Overweight/ } \\
\text { obese }(\boldsymbol{n}=\mathbf{4 1})\end{array}$ & $p$-Value \\
\hline $\begin{array}{l}\text { Mastectomy } \\
\text { weight (g) }\end{array}$ & $472.8 \pm 181.8$ & $692.8 \pm 261.1$ & $<0.01$ \\
\hline $\begin{array}{l}\text { Flap weight: } \\
\text { initial (g) }\end{array}$ & $559.6 \pm 179.6$ & $1,059.3 \pm 445.7$ & $<0.01$ \\
\hline $\begin{array}{l}\text { Flap weight: } \\
\text { final (g) }\end{array}$ & $533.5 \pm 183.8$ & $813.9 \pm 242.7$ & $<0.01$ \\
\hline $\begin{array}{l}\text { Perforators } \\
\text { per flap (n) }\end{array}$ & $1.5 \pm 0.5$ & $1.6 \pm 0.5$ & 0.30 \\
\hline $\begin{array}{l}\text { Second flap } \\
\text { anastomosed } \\
\text { to retrograde } \\
\text { IMA (\%) }\end{array}$ & $23(76.7)$ & $30(73.1)$ & 0.34 \\
\hline $\begin{array}{l}\text { Second flap } \\
\text { anastomosed } \\
\text { to primary } \\
\text { flap (\%) }\end{array}$ & $7(23.3)$ & $11(26.8)$ & 0.34 \\
\hline $\begin{array}{l}\text { Concurrent } \\
\text { contralateral } \\
\text { procedure (\%) }\end{array}$ & $6(20.0)$ & $15(36.6)$ & 0.10 \\
\hline $\begin{array}{l}\text { Delayed } \\
\text { reconstruction } \\
\text { (\%) }\end{array}$ & $15(50.0)$ & $21(51.2)$ & 0.42 \\
\hline
\end{tabular}

Abbreviation: IMA, internal mammary artery.

$28.9 \pm 4.0 \mathrm{~kg} / \mathrm{m}^{2}(p<0.01)$. Age at reconstruction was similar in both groups (normal $\mathrm{BMI}=52.8 \pm 7.9$, overweight/obese $=53.2 \pm 8.9 ; p=0.42$ ). The only difference in comorbidities that approached statistical significance was in the rate of hypertension as the normal BMI patients were less likely to be hypertensive at baseline than were the overweight or obese patients (normal $\mathrm{BMI}=16.7 \%$, overweight $/$ obese $=34.1 \%$; $p=0.06$ ). Diabetes was more prevalent in the overweight/obese group as well, but this finding did not reach statistical significance (normal BMI $=3.3 \%$, overweight $/$ obese $=7.3 \% ; p=0.25$ ). There was no statistically significant difference in the rate of chemotherapy or radiotherapy between groups ( - Table $\mathbf{1}$ ).

Mastectomy specimen weights were greater in the overweight/obese group than in the normal BMI group (normal $\mathrm{BMI}=472.8 \pm 181.9 \mathrm{~g}, \quad$ overweight $/$ obese $=692.8 \pm 261.1 \mathrm{~g}$; $p<0.01$ ). Similarly, the weight of the conjoined flaps at the time of harvest, as well as the final weight of each conjoined DIEP flap, following shaping and insetting were greater in the overweight/obese group. Patients in the overweight/obese group were more likely to have concomitant contralateral procedures but this difference did not achieve statistical significance (-Table 2).

Overall, the rate of major complications observed in the two groups was similar (normal $\mathrm{BMI}=10.0 \%$, overweight/ obese $=12.1 \% ; p=0.39$ ). Three patients in each group required return to the operating room during their initial hospitalization. There was one partial flap loss and one pulmonary embolism in the overweight/obese group. There were no partial flap losses or pulmonary emboli in the normal group. There were no total flap losses in either group ( - Table 3 ). The same holds true when examining only obese
Table 3 Major complications

\begin{tabular}{|l|l|l|l|}
\hline & $\begin{array}{l}\text { Normal } \\
(\boldsymbol{n}=\mathbf{3 0})\end{array}$ & $\begin{array}{l}\text { Overweight/ } \\
\text { obese }(\boldsymbol{n}=\mathbf{4 1})\end{array}$ & $p$-Value \\
\hline Return to OR (\%) & $3(10.0)$ & $3(7.3)$ & 0.39 \\
\hline Partial flap loss (\%) & $0(0)$ & $1(2.4)$ & 0.20 \\
\hline Total flap loss (\%) & $0(0)$ & $0(0)$ & NA \\
\hline $\begin{array}{l}\text { Pulmonary } \\
\text { embolism (\%) }\end{array}$ & $0(0)$ & $1(2.4)$ & 0.19 \\
\hline $\begin{array}{l}\text { Symptomatic } \\
\text { bulge (\%) }\end{array}$ & $0(0)$ & $0(0)$ & NA \\
\hline Total (\%) & $3(10.0)$ & $5(12.2)$ & 0.39 \\
\hline
\end{tabular}

Abbreviations: NA, not available; OR, odds ratio.

Table 4 Minor complications

\begin{tabular}{|l|l|l|l|}
\hline & $\begin{array}{l}\text { Normal } \\
(\boldsymbol{n}=\mathbf{3 0})\end{array}$ & $\begin{array}{l}\text { Overweight } / \\
\text { obese }(\boldsymbol{n}=\mathbf{4 1})\end{array}$ & $p$-Value \\
\hline Breast (\%) & & & \\
\hline Wound & $3(10.0)$ & $5(12.1)$ & 0.39 \\
\hline Hematoma & $0(0)$ & $0(0)$ & NA \\
\hline Seroma & $4(13.3)$ & $0(0)$ & $<0.01$ \\
\hline Infection & $1(3.3)$ & $2(4.9)$ & 0.11 \\
\hline Persistent edema & $2(6.7)$ & $1(2.4)$ & 0.19 \\
\hline Donor site (\%) & & & \\
\hline Wound & $2(6.7)$ & $5(12.2)$ & 0.22 \\
\hline Hematoma & $1(3.3)$ & $1(2.4)$ & 0.41 \\
\hline Seroma & $2(6.7)$ & $4(9.8)$ & 0.32 \\
\hline Infection & $0(0)$ & $0(0)$ & NA \\
\hline Total percentage $(n)$ & $36.7 \%(11)$ & $39.9 \%(16)$ & 0.47 \\
\hline
\end{tabular}

Abbreviation: NA, not available.

Note: Certain patients experienced more than one minor complication; the total percentage of complications reflects the number of patients who experienced at least one minor complication.

patients (BMI $>30, n=8$ ), as there was only one major complication (partial flap loss) observed in this subgroup.

There was a trend toward the occurrence of more minor complications in the overweight/obese group, but this difference did not reach statistical significance (normal BMI $=36.7 \%$, overweight $/$ obese $=39.0 \% ; p=0.47$ ). More wound complications at both the donor site and the recipient site were observed in the overweight/obese group than in the normal BMI group; neither finding reached statistical significance. More breast seromas were observed in the normal BMI group than in the overweight/obese group (normal $\mathrm{BMI}=13.3 \%, \quad$ overweight $/$ obese $=0.0 \% ; \quad p<0.01$ ). There were no other statistically significant differences in the minor complications between the two groups (-Table 4).

A trend toward a higher rate of mild fat necrosis was observed in the overweight/obese group, but this trend did not reach statistical significance. However, we did observe a statistically significant increase in the rate of moderate fat necrosis in the overweight/obese group ( - Table 5 ). 
Table 5 Fat necrosis

\begin{tabular}{|l|l|l|l|}
\hline & $\begin{array}{l}\text { Normal } \\
(\boldsymbol{n}=30)\end{array}$ & $\begin{array}{l}\text { Overweight/ } \\
\text { obese }(\boldsymbol{n}=\mathbf{4 1})\end{array}$ & $p$-Value \\
\hline Mild $<2 \mathrm{~cm} \mathrm{( \% )}$ & $5(16.7)$ & $8(19.5)$ & 0.38 \\
\hline Moderate $>2 \mathrm{~cm}(\%)$ & $0(0)$ & $4(9.8)$ & 0.04 \\
\hline Total (\%) & $5(16.7)$ & $12(29.3)$ & 0.12 \\
\hline
\end{tabular}

\section{Discussion}

The incidence of major complications of approximately $10 \%$ experienced by both normal and overweight/obese BMI cohorts who underwent unilateral bipedicle-conjoined DIEP flap breast reconstruction was nearly identical ( - Table 3 ). This observation $(\sim 10 \%)$ is consistent with published norms for microsurgical breast reconstruction. ${ }^{15,16}$ These findings suggest that using bipedicle-conjoined DIEP flaps for unilateral breast reconstruction is safe across a wide spectrum of body mass indices. It is, however, prudent to recognize that certain minor complications will likely be more prevalent in overweight or obese patients. The overweight and obese patients in our series experienced more frequent wound complications in their reconstructed breasts and at their abdominal donor sites. Similarly, they were more likely to develop both mild and moderate fat necrosis. Though only the difference in the rate of moderate fat necrosis reached statistical significance, the observed trends suggest that one should expect more wound complications and fat necrosis in overweight and obese patients than in patients with a BMI $\leq 25$. Higher rates of complications in patients with a BMI $\geq 25$ undergoing breast reconstruction has been well documented and is not exclusive to any particular technique. ${ }^{12-14,17}$ Patients should be counseled accordingly with particular attention paid to proper risk

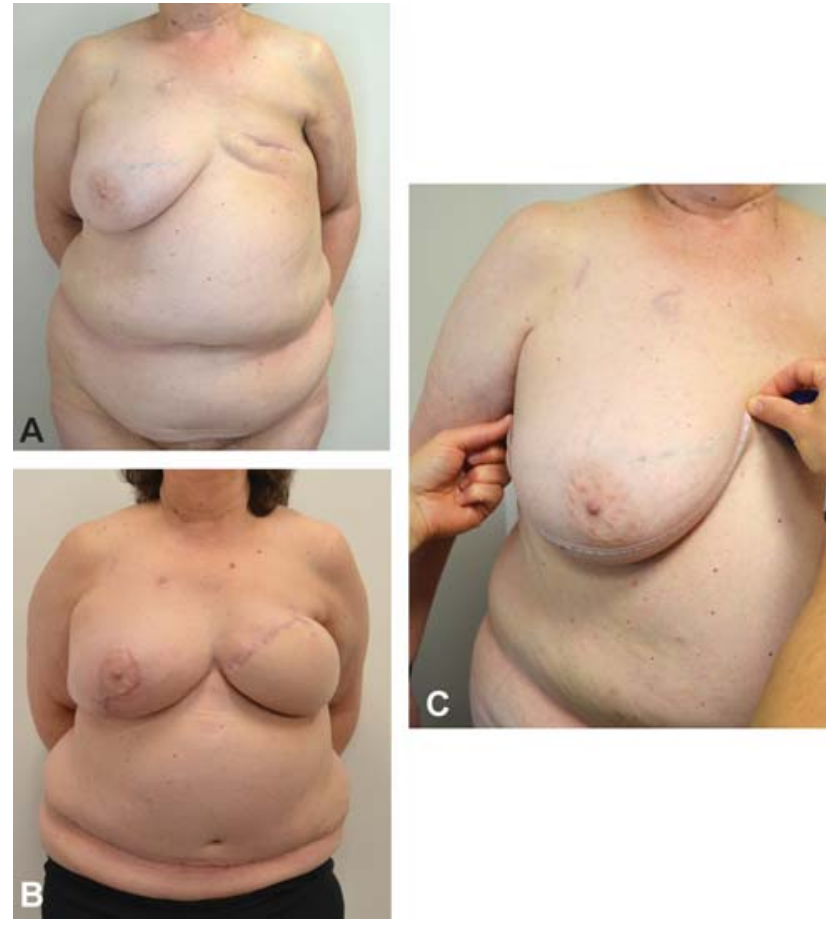

Fig. 2 This patient $(\mathrm{BMI}=33.9)$ presented for delayed breast reconstruction following mastectomy and subsequent radiation therapy (A). The senior authors' preoperative assessment includes topographic surface measurements to determine the dimension of skin required to create an adequately projected and ptotic breast. In this case it was determined that the reconstruction would necessitate approximately $40 \mathrm{~cm}$ of skin in its greatest dimension (B). Despite the patient's large abdominal pannus, it was clear that a hemi-abdominal flap would not provide adequate skin nor volume to allow for reconstruction to match that of the contralateral breast. The postoperative position of the umbilical aperture in the bipedicleconjoined flap is illustrative in this case of how deficient of skin a hemiabdominal flap would have been. The patient is shown following revision of her left breast reconstruction and balancing reduction of the contralateral breast (C). BMI, body mass index.
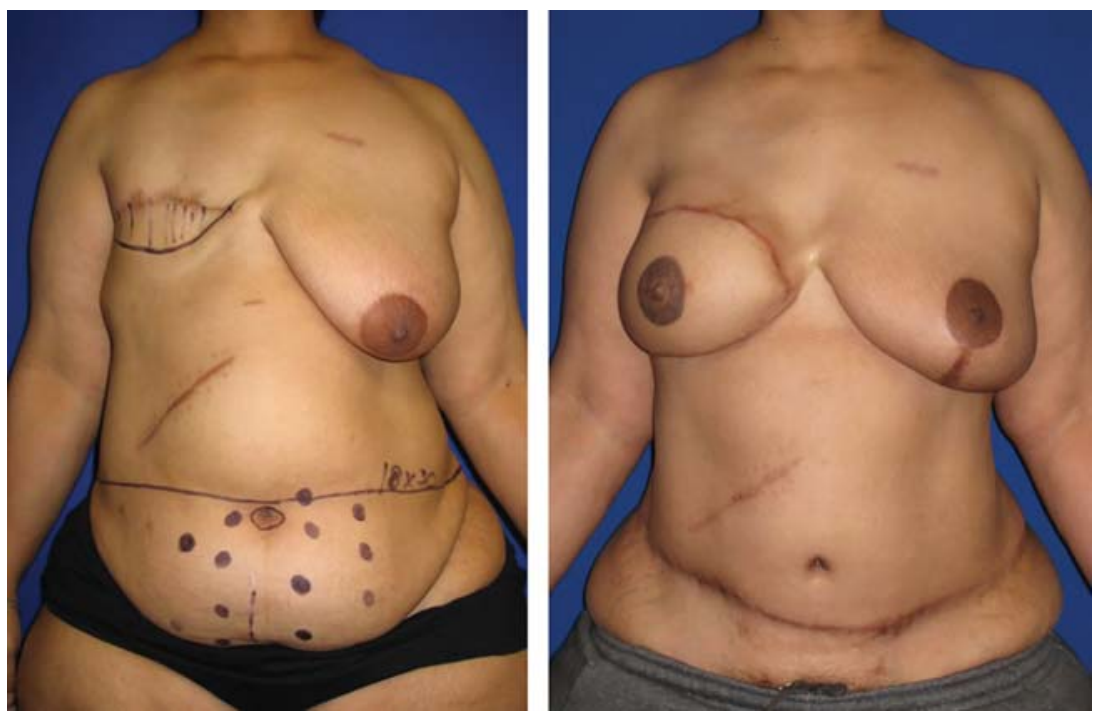

Fig. 1 This patient $(B M I=34.8)$ presented for delayed breast reconstruction in 2008, 3 years after her mastectomy. At the time of her reconstruction, the senior authors did not perform bipedicle-conjoined DIEP flaps in overweight patients. As such, she underwent unilateral reconstruction with a left DIEP flap (777 g; mastectomy weight unknown). Despite her overhanging pannus, her reconstruction is deficient of both volume and skin when compared with the contralateral side (even after subsequent contralateral reduction). In the authors' current practice, this patient would be reconstructed using bipedicle-conjoined flaps. BMI, body mass index; DIEP, deep inferior epigastric perforator. 

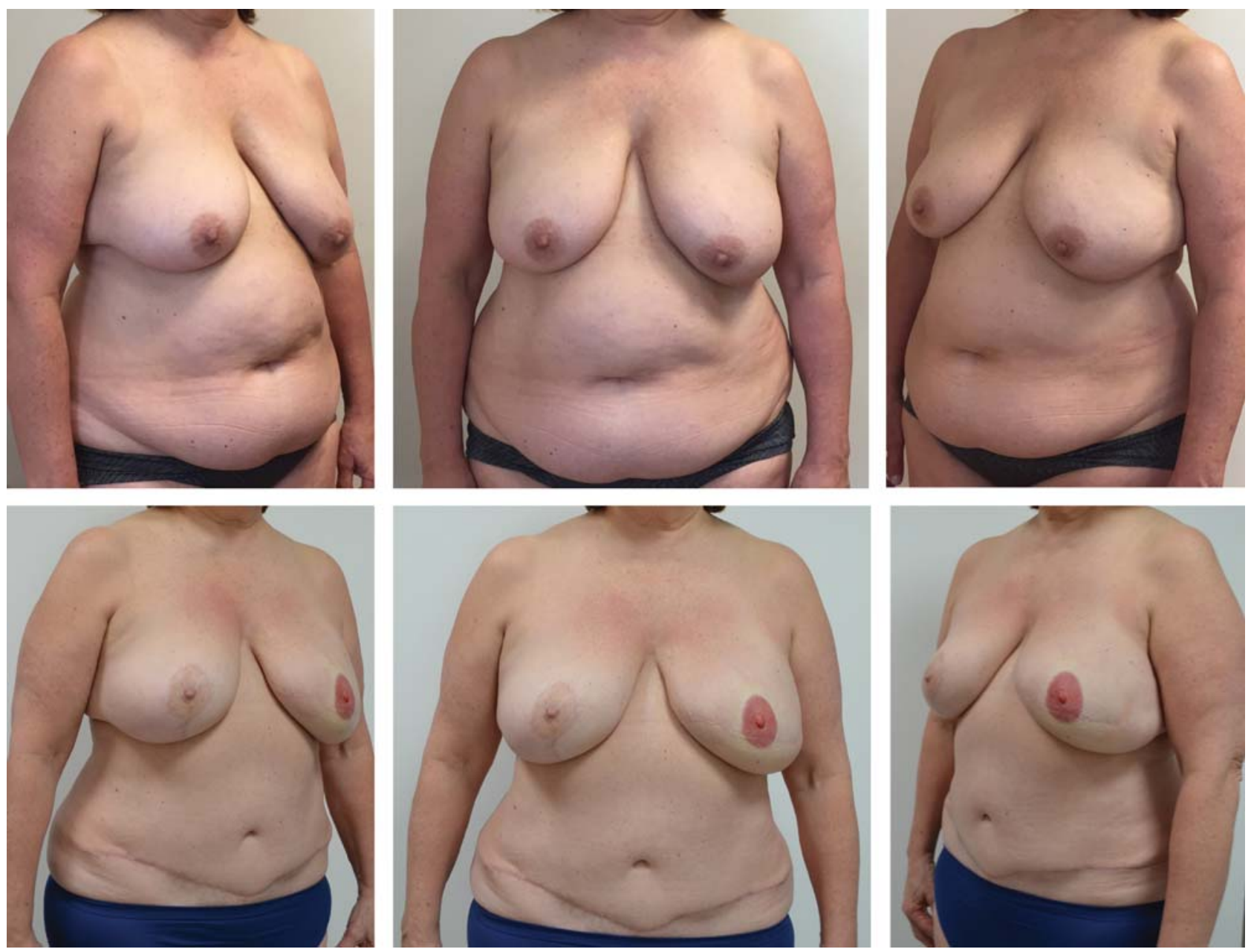

Fig. 3 This patient $(\mathrm{BMI}=31.0)$ presented for immediate breast reconstruction. It was determined preoperatively that she would require a bipedicle-conjoined flap to restore adequate volume to her reconstructed breast, despite her significant pannus and a planned concurrent contralateral mastopexy. Her left mastectomy weight was $937 \mathrm{~g}$. Her bipedicle-conjoined flap weight was $1,484 \mathrm{~g}$ initially and $1,026 \mathrm{~g}$ after trimming. She is shown postoperatively (below) following a single revision of her abdominal donor site scar and nipple-areola complex creation. BMI, body mass index.

stratification and prophylaxis for thromboembolic events using the Caprini's Risk Assessment score.

Despite the increased prevalence of minor complications in overweight and obese patients, we believe that the use of bipedicle-conjoined DIEP flaps for unilateral reconstruction is of great utility in this population and that the benefits frequently outweigh the risks.

The modern approach to reconstructing a breast in an aesthetic fashion was laid out in a four-part series in 2009 by Blondeel et al. ${ }^{18-21}$ In this series, the authors stress importance of restoring three essential elements of the breast: the footprint, conus, and skin envelope. Adoption of approaches that satisfy these criteria has undoubtedly led to refinements in bipedicle-conjoined DIEP flap reconstruction for unilateral defects and to the use of four-flap solutions for bilateral breast reconstruction. ${ }^{22-27}$ Published reports suggest that these techniques have thus far been applied predominantly to patients with a normal or low BMI. While many overweight and obese patients possess what many surgeons would consider "adequate" abdominal tissue for standard reconstruction, many of these recon- structions will fall short in restoring one or more of the three essential parameters necessary to achieve an aesthetic reconstruction when only a single pedicle flap is utilized. A three-zone single-pedicle flap may transpose adequate tissue for reconstruction; however, it is the experience of the authors that perfusion in this configuration is less reliable than that of a bipedicle-conjoined flap.

Patients with a higher BMI often have breasts characterized by a large volume of parenchyma and a wide base diameter. These patients therefore have a correspondingly large breast footprint and/or conus required to achieve an aesthetically pleasing reconstruction. For unilateral reconstruction, it has been the experience of the senior authors that a single pedicle DIEP flap frequently does not provide adequate skin, and soft tissue volume, in the optimal and proportions and dimensions, to reconstruct the anatomic elements of the breast needed to achieve aesthetically acceptable results, and/or to match the contralateral breast, even when the contralateral breast is

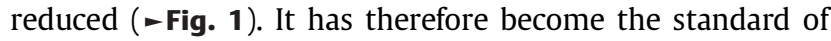
practice of the authors, regardless of a patient's preoperative $\mathrm{BMI}$, to employ bipedicle-conjoined flaps to improve outcomes 

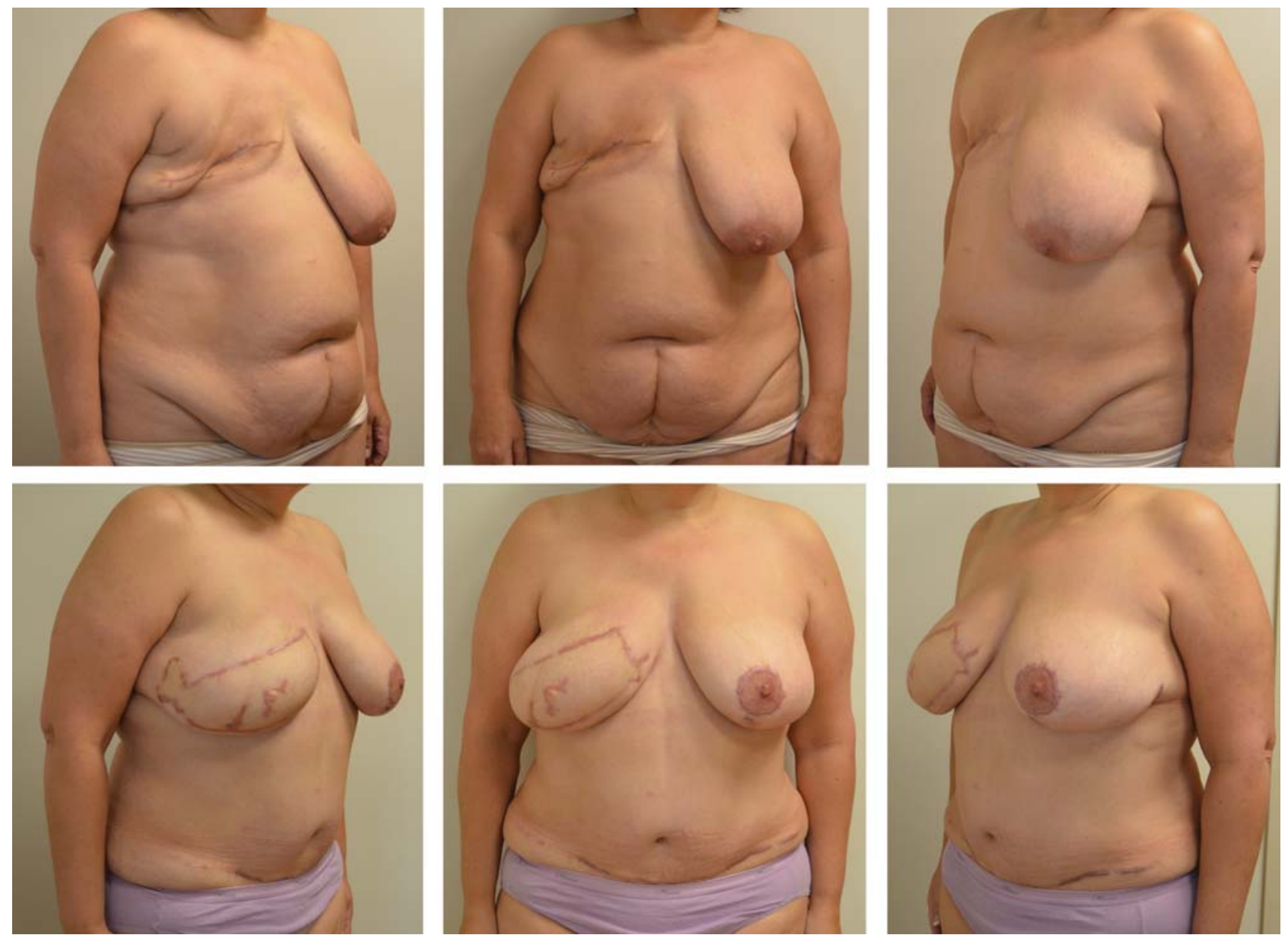

Fig. 4 This patient $(\mathrm{BMI}=39.0)$ presented for delayed breast reconstruction. It was determined preoperatively that she would require a bipedicle-conjoined flap to restore both her skin envelope and an adequate volume to create a symmetric conus, despite her significant pannus and a planned concurrent contralateral mastopexy. Additionally, she had a prior lower midline laparotomy that would decrease the reliability of a single-pedicle three-zone flap. Her mastectomy weight was unknown. Her bipedicle-conjoined flap weight was $1,603 \mathrm{~g}$ initially and $1,215 \mathrm{~g}$ after trimming. She is shown postoperatively (below) following a single revision consisting of excision of a small area $(<2 \mathrm{~cm})$ of fat necrosis, abdominal scar revision with donor site liposuction and nipple creation. BMI, body mass index.

in situations where a single-pedicle flap is deemed insufficient to restore the footprint or conus (-Fig. 2 ).

Overweight or obese patients that are reconstructed in an immediate fashion may require bipedicle-conjoined flaps to restore adequate volume of the reconstructed breast (-Fig. 3). The same cohort of patients reconstructed in a delayed fashion may require not only more volume than a hemiabdominal flap may provide, but a larger area of skin as well. Inadequate reconstruction of the skin envelope leads to flattening of the breast and a lack of natural appearing ptosis. The senior authors therefore routinely employ bipedicleconjoined flaps in these cases (-Fig. 4).

\section{Conclusion}

For many overweight or obese patients with unilateral reconstructive requirements, single-pedicle flaps or implant-based reconstruction will be inadequate. Our data demonstrate that bipedicle-conjoined DIEP flap reconstruction can be performed safely in overweight and obese patients with morbidity on par with that observed in "normal" weight patients. As the average BMI of women continues to increase nationally, it is imperative that plastic surgeons expand the indications for autologous reconstruction to parallel this demographic shift and better meet the needs of our patients. ${ }^{28}$

\section{Note}

None of the authors has financial interest in any of the products, devices, or drugs mentioned in this manuscript.

\section{Conflict of Interest}

None declared.

\section{References}

1 Ishii CH Jr., Bostwick J III, Raine TJ, Coleman JJ III, Hester TR. Double-pedicle transverse rectus abdominis myocutaneous flap for unilateral breast and chest-wall reconstruction. Plast Reconstr Surg 1985;76(06):901-907

2 Spear SL, Travaglino-Parda RL, Stefan MM. The stacked transverse rectus abdominis musculocutaneous flap revisited in breast reconstruction. Ann Plast Surg 1994;32(06):565-571 
3 Murray A, Wasiak J, Rozen WM, Ferris S, Grinsell D. Stacked abdominal flap for unilateral breast reconstruction. J Reconstr Microsurg 2015;31(03):179-186

4 Ng RL, Youssef A, Kronowitz SJ, Lipa JE, Potochny J, Reece GP. Technical variations of the bipedicled TRAM flap in unilateral breast reconstruction: effects of conventional versus microsurgical techniques of pedicle transfer on complications rates. Plast Reconstr Surg 2004;114(02):374-384, discussion 385-388

5 Seth AK, Koolen PGL, Sultan SM, Lee BT, Erhard HA, Greenspun DT. Unilateral autologous breast reconstruction with bi-pedicled, conjoined deep inferior epigastric perforator flaps. J Reconstr Microsurg 2019;35(02):145-155

6 Hamdi M, Khuthaila DK, Van Landuyt K, Roche N, Monstrey S. Double-pedicle abdominal perforator free flaps for unilateral breast reconstruction: new horizons in microsurgical tissue transfer to the breast. J Plast Reconstr Aesthet Surg 2007;60 (08):904-912, discussion 913-914

7 Blondeel PN, Boeckx WD. Refinements in free flap breast reconstruction: the free bilateral deep inferior epigastric perforator flap anastomosed to the internal mammary artery. Br J Plast Surg 1994;47(07):495-501

8 Figus A, Fioramonti P, Ramakrishnan V. Stacked free SIEA/DIEP flap for unilateral breast reconstruction in a thin patient with an abdominal vertical midline scar. J Reconstr Microsurg 2007;23 (08):523-525

9 Koolen PG, Lee BT, Lin SJ, Erhard HA, Greenspun DT. Bipedicleconjoined perforator flaps in breast reconstruction. J Surg Res 2015;197(02):256-264

10 Kantak NA, Koolen PG, Martin C, Tobias AM, Lee BT, Lin SJ. Are patients with low body mass index candidates for deep inferior epigastric perforator flaps for unilateral breast reconstruction? Microsurgery 2015;35(06):421-427

11 DellaCroce FJ, Sullivan SK, Trahan C. Stacked deep inferior epigastric perforator flap breast reconstruction: a review of 110 flaps in 55 cases over 3 years. Plast Reconstr Surg 2011;127(03):1093-1099

12 Huo J, Smith BD, Giordano SH, Reece GP, Shih YT. Post-mastectomy breast reconstruction and its subsequent complications: a comparison between obese and non-obese women with breast cancer. Breast Cancer Res Treat 2016;157(02):373-383

13 Fischer JP, Nelson JA, Kovach SJ, Serletti JM, Wu LC, Kanchwala S. Impact of obesity on outcomes in breast reconstruction: analysis of 15,937 patients from the ACS-NSQIP datasets. J Am Coll Surg 2013;217(04):656-664

14 Huo J, Smith BD, Giordano SH, Reece GP, Tina Shih YC. A comparison of patient-centered economic and clinical outcomes of postmastectomy breast reconstruction between obese and non-obese patients. Breast 2016;30:118-124

15 Vega S, Smartt JM Jr., Jiang S, et al. 500 Consecutive patients with free TRAM flap breast reconstruction: a single surgeon's experience. Plast Reconstr Surg 2008;122(02):329-339
16 Fischer JP, Sieber B, Nelson JA, et al. Comprehensive outcome and cost analysis of free tissue transfer for breast reconstruction: an experience with 1303 flaps. Plast Reconstr Surg 2013;131(02): 195-203

17 Jandali S, Nelson JA, Sonnad SS, et al. Breast reconstruction with free tissue transfer from the abdomen in the morbidly obese. Plast Reconstr Surg 2011;127(06):2206-2213

18 Blondeel PN, Hijjawi J, Depypere H, Roche N, Van Landuyt K. Shaping the breast in aesthetic and reconstructive breast surgery: an easy three-step principle. Part IV-aesthetic breast surgery. Plast Reconstr Surg 2009;124(02):372-382

19 Blondeel PN, Hijjawi J, Depypere H, Roche N, Van Landuyt K. Shaping the breast in aesthetic and reconstructive breast surgery: an easy three-step principle. Part III-reconstruction following breast conservative treatment. Plast Reconstr Surg 2009;124(01): 28-38

20 Blondeel PN, Hijjawi J, Depypere H, Roche N, Van Landuyt K. Shaping the breast in aesthetic and reconstructive breast surgery: an easy three-step principle. Part II-Breast reconstruction after total mastectomy. Plast Reconstr Surg 2009;123(03):794-805

21 Blondeel PN, Hijjawi J, Depypere H, Roche N, Van Landuyt K. Shaping the breast in aesthetic and reconstructive breast surgery: an easy three-step principle. Plast Reconstr Surg 2009;123(02): 455-462

22 Mohan AT, Patel NG, Malata CM. Combination of the superior and inferior pedicle "continuities" for anastomosis of an SIEA flap to a contralateral DIEP flap in double-pedicled abdominal free flaps: A further modification of the Hamdi classification. J Plast Reconstr Aesthet Surg 2014;67(10):e237-e239

23 Rabey NG, Erel E, Malata CM. Double-pedicled abdominal free flap using an entirely new microvascular combination of DIEP and SIEA vascular pedicles for unilateral breast reconstruction: a novel addition to the Hamdi classification. Plast Reconstr Surg 2012;130(05):767e-769e

24 Malata CM, Rabey NG. Decision making in double-pedicled DIEP and SIEA abdominal free flap breast reconstructions: an algorithmic approach and comprehensive classification. Front Surg 2015; 2:49

25 Mayo JL, Allen RJ, Sadeghi A. Four-flap breast reconstruction: bilateral stacked DIEP and PAP flaps. Plast Reconstr Surg Glob Open 2015;3(05):e383

26 Patel NG, Rozen WM, Chow WT, et al. Stacked and bipedicled abdominal free flaps for breast reconstruction: considerations for shaping. Gland Surg 2016;5(02):115-121

27 Rozen WM, Patel NG, Craggs BS, Ramakrishnan VV. Four-Flap Breast Reconstruction with Bilateral Stacked Flaps. Plast Reconstr Surg 2016;137(02):492e-493e

28 Flegal KM, Kruszon-Moran D, Carroll MD, Fryar CD, Ogden CL. Trends in Obesity Among Adults in the United States, 2005 to 2014. JAMA 2016;315(21):2284-2291 